\title{
Gender and the social imaginary in medieval Welsh law
}

\author{
Robin Chapman Stacey
}

Sir John Rhŷs Memorial Lecture, read 26 March 2019.

Abstract: This talk explores the role played by gender in the social imaginaries implicit in medieval Welsh law. It takes as its starting point the lawbooks of medieval Wales, which have narrative qualities rendering them susceptible to analyses of several different kinds, from standard historical readings, to scrutiny as law, to more literary critical methods. Of particular interest in this lecture are the ways in which ideas about male and female inform lawbook depictions of space and time, sexuality in both animal and human bodies, and everyday practices such as farming.

Keywords: Gender, Welsh law, space, farming, sexuality, social imaginary.

Note on the author: Robin Chapman Stacey is Professor of History at the University of Washington. She is the author of several books and articles on medieval Irish and Welsh law, including The Road to Judgment: From Custom to Court in Medieval Ireland and Wales (University of Pennsylvania Press, 1994), Dark Speech: The Performance of Law in Early Ireland (University of Pennsylvania Press, 2007), and Law and the Imagination in Medieval Wales (University of Pennsylvania Press, 2018). rcstacey@uw.edu

(C) The author(s) 2020. This is an open access article licensed under a Creative Commons Attribution-NonCommercial-NoDerivs 4.0 Unported License 
It was an honour to be invited to deliver the Sir John Rhŷs Memorial Lecture, not least because of the opportunity afforded me by this occasion to pay tribute to the achievements of Sir John Rhŷs himself, the very first professor of Celtic at Oxford University and a scholar whose work continues to inspire more than a century after his death. In fact, it was Rhŷs' noting of the omission of women from the hierarchical seating arrangements outlined in the medieval Welsh lawbooks for the royal court that initially suggested my topic for this essay. 'In regard to this order of precedence', he wrote with co-author David Brynmor-Jones in The Welsh People, published in 1900,

we notice first of all the absence of all reference to the queen or other ladies, and we feel inclined to infer from this fact that it has reference, not to the ordinary life of the chieftain and his establishment, but to the formal occasion of some ceremonial Court, probably the solemn meetings of the household on the three principal festivals, of which we have mention, or other similar assemblies. ${ }^{1}$

Now, it might be objected that this is on its face unlikely to be a full explanation, queens and women generally liking a good festival as much as the next person and presumably needing to sit somewhere. Moreover, the opposition Rhŷs presumes between 'female' and 'solemn meetings of the household' would strike many scholars nowadays as a phenomenon requiring further study rather than an answer in itself. However, the fact that he would even note their absence, much less regard it as an anomaly requiring clarification, in a period so long before women's history had really established itself as a field, is striking. In this as in much else, Rhŷs missed little of importance.

For their absence is, as I will argue here, important, or at least the reporting of it is: part of a larger textual phenomenon, the crafting by medieval Welsh lawyers of a highly gendered vision of court and country. The sources on which I will be drawing in this essay are of two different types. The Welsh lawbooks are extant today in about forty manuscripts dating from the early 13th through to the early 16th century, in both Welsh and Latin. There are two basic traditions: one associated with the northern kingdom of Gwynedd and one with the southern realm of Deheubarth, and several different textual families. The fact that the lawbooks survive in such numbers is itself an indication of how important a venture they were thought to be; they were and are amongst the most significant components of the medieval prose tradition. I will be drawing mainly here on the most professional and politically aware of these lawbooks, the 'Book of Iorwerth' (Llyfr Iorwerth), the initial composition of which is attributed to Iorwerth ap Madog, a northern jurist of the first half of the 13th century. Much less numerous, though of similar date, is my second type of source, the Welsh pleading

${ }^{1}$ Rhŷs \& Brynmor-Jones (1900: 201). 
texts, which consist largely of model pleas to be used in disputes. Both types of texts are thought to have been composed by lawyers for the purposes of instructing future members of their profession. ${ }^{2}$ Oddly, what do not survive from pre-Conquest Wales are records of actual court cases. Perhaps records of this sort once existed but are no longer extant; perhaps law was thought to be written but justice oral, as may also have been the case in early Ireland, where a similar phenomenon occurs. ${ }^{3}$

Legal texts traditionally do not enjoy a reputation for being particularly diverting and, in truth, the lawbooks can be profitably read in a more or less literal way, as sober, if stylised, accounts of Welsh legal practice. Indeed, it is from the laws that we know much of what we do about the workings of medieval Welsh society, in large part because the court records mentioned earlier do not survive. However, recent work has also made us aware that there are significant narrative aspects to these texts, and even flashes of humour, so a literal reading is not the only means of approaching them. ${ }^{4}$ Even more importantly, it has become clear through the excellent work of scholars like Huw Pryce and David Stephenson that the lawbooks, in addition to being the means by which the legal tradition was preserved and perpetuated, functioned as an important outlet for political expression for members of the uchelwyr, 'noble' or 'freeborn' class from which their authors are believed to have come. Certain passages appear to comment - albeit obliquely — on pressing issues of the day, including the increasingly autocratic nature of native Welsh rule; transgressions by royal officials on the traditional rights of freemen; divisions between north and south Wales; native attitudes towards divorce; the dangers of disunity; and the abandonment of native law by Welshmen in favour of English custom. ${ }^{5}$ This may explain why the Welsh themselves thought these texts so important. Far more copies and redactional variants exist of the laws than of the considerably more famous prose Mabinogion tales, for example. These texts really mattered: in no other way can we explain the effort expended upon them. ${ }^{6}$

\footnotetext{
${ }^{2}$ Charles-Edwards (1986); Stacey (2004).

${ }^{3}$ Charles-Edwards (1989; 2013: 245-73); see also the Cyfraith Hywel website, which provides an excellent introduction to the Welsh legal corpus and can be accessed at: http://cyfraith-hywel.cymru.ac.uk/en/ index.php

${ }^{4}$ Stacey (2018); Pryce (1986, 1993, 1998, 2000a: 50-63); Stephenson (2000).

${ }^{5}$ Pryce (1986, 1998, 2000); Stephenson (2000); Stacey (2002, 2018).

${ }^{6}$ The lawbooks themselves enjoin their use, and some legal manuscripts show signs of actual use (Owen (1841): Ancient Laws of Wales (hereafter $A L W$ ), III, Llyvyr Pra6v). Latin C (British Library Harleian MS 1796) may be an example of such a manuscript (Russell 2011: xviii, xliii). Peniarth 28 may have been a presentation copy (Huws 1975-76: 340-4, 1988, Pryce (1993: 28, n. 47). For descriptions of individual manuscripts, see the Cyfraith Hywel website: http://cyfraith-hywel.cymru.ac.uk/en/index.php. For an excellent modern translation of the northern tradition of Iorwerth, see Jenkins (1986).
} 
Significantly, very little of the jurists' commentary takes the form of directly articulated criticism. Rather, the authors of the lawbooks communicated their views through what appear to be-well, laws-governing the legal practices of medieval Wales. But as is so often the case with sources authored by parties with a stake in the outcome, what presents itself as description might more accurately to be termed depiction, an imagined construction of reality rather than a faithful reproduction of it. To put the matter another way: the lawbooks constitute narratives of legitimisation as well as descriptions of legal practice. They represent attempts by the jurists to construct the culture in which they lived in ways that are sometimes deliberately agenda driven. One key aspect of their work is the creation and dissemination of what scholars refer to as 'social imaginaries': constructs, metaphors, and symbolic structures through which cultures characterise themselves, or are characterised by others, as social entities. ${ }^{7}$ Many take the form of binomials, such as 'man and woman', 'old and young', 'poor and rich', 'free and unfree', 'clerical and lay'. However, some of the best known are tripartite in nature, such as Georges Duby's 'three orders' or Georges Dumézil's 'three functions'. ${ }^{8}$ Rarely are these formulations mutually exclusive-indeed, often they reinforce one another. As historian Cordelia Hess remarks, 'in any cultural and historical context, there are always several different images for the social order, which together form a somewhat coherent imagery. This imagery in turn signifies "society", not as a faithful representation, but as a narrative of power relations and meaning."

My article will be structured around the two constituent halves of one such imaginary, a binomial suggested by the layout of the lawbooks themselves. All principal lawbook versions were originally divided into two parts - the first, the 'Laws of Court', describing the royal court and its personnel, and the second, the 'Laws of Country', describing the customs of the realm over which that court is pictured as ruling. Historians and archaeologists have written fruitfully about court and country as real-life historical venues. ${ }^{10}$ As depicted in the lawbooks, however, they function also as symbols of concepts larger than themselves: images of the social order and metonyms of the nation as a political and social whole. Historically unlocalisable and geographically ubiquitous, court and country as presented in the laws are true imaginaries - detached from any specific king or era and thus, by implication, applicable to them all. Even the pleading texts, which lack the ideological stature and import of the

\footnotetext{
${ }^{7}$ Suggested reading includes: Taylor (2003, 2004); Steger (2008).

${ }^{8}$ Duby (1982). Theodore Evergates terms this a 'feudal imaginary' (Evergates (1997: 641-60, see Oexle 2001: 92-143). Georges Dumézil's 'three functions' would be another example (Dumézil 1968, 1979), and yet another would be the organic analogy, in which the state is conceptualised as a body, which appears in a wide range of literature, from the Bible to Durkheim and beyond (Kantorowicz 1957, John of Salisbury 1990, Douglas 1990: 395-9, Dunn 2016).

${ }^{9}$ Hess (2013: 3).

${ }^{10}$ Essays by G. R. J. Jones, T. M. Charles-Edwards, R. C. Stacey, and M. Phillips in Charles-Edwards et al. (2000a: 296-361); see also Stacey (2018: 56-88) and references there.
} 
lawbooks, focus similarly on a gwlad or country that is untethered to time or region.

Court and country will set the boundaries of my investigation, but my specific focus is gender: concepts of maleness and femaleness as constructed within and by these legal writings. A natural starting point is Joan Wallach Scott's 'Gender: A Useful Category of Historical Analysis' which, though published in 1986, continues to inspire gender scholars of all eras. Scott urged historians to put gender at the centre of their political histories because, she argued, gender has always been at the centre of politics itself. ${ }^{11}$ Her work remains required reading for anyone who would understand why, for example, male candidates have more of a chance of being elected if they are married and have gone to war, or why former Prime Minister Theresa May's fashion choices should have excited such impassioned debate during her term in office. Many UK citizens are probably aware at this point of the political implications of the leopardprint 'kitten heel'; ${ }^{12}$ some may additionally recall the headlines from the Telegraph and BBC News, respectively, 'Why Theresa May Shouldn't Wear Flat Shoes in the Name of Equality', and 'Theresa May's Leather Trousers Prompt Political Row'. ${ }^{13}$ Nor has Theresa May been alone in manipulating gendered imagery in this way. Margaret Thatcher consciously made use of both male and female gender stereotypes in her stint as Prime Minister, having herself photographed shopping for groceries on the one hand, and riding in a war tank on the other. ${ }^{14}$ Nigel Farage has similarly been pictured on, though rather uncomfortably not in, a war tank. ${ }^{15}$ And one of the most unforgettable images of Donald Trump ever produced shows him standing on a tank with gold-plated treads, brandishing a semi-automatic rifle while bombs burst around his head and a clearly terrified bald eagle tries desperately to get out of the way. ${ }^{16}$

Images like these make it clear that Scott was right to see politics and gender as inextricably linked to one another not merely in France, where her own early work was centred, but in a variety of historical societies worldwide. Scott grounded her definition

\footnotetext{
${ }^{11}$ Scott (1986, 2010: 7-14); Butler \& Weed (2011).

${ }^{12}$ Teeman (2016); Conti (2016); Daley (2016).

${ }^{13}$ Thorp (2016); Moseley (2016); Pithers (2017). However, only those truly in the know will be aware of her habit of wearing chunky necklaces on the days she gave bad news to Parliament, as one reporter remarked 'framing both her face and her policies, wreathing them in brute force' (Pilcher 2013).

${ }^{14}$ For sample images relating to former Prime Minister Margaret Thatcher, see: Getty Images, 'Margaret Thatcher holding up two shopping bags', https://www.gettyimages.co.uk/detail/news-photo/conservativeparty-leader-margaret-thatcher-holding-up-two-news-photo/562660935; Alamy Stock Photos, 'Mrs Thatcher shopping', https://www.alamy.com/stock-photo-mrs-thatcher-shopping-1979-106532908.html; and Alamy Stock Photos, 'Margaret Thatcher riding in tank' https://www.alamy.com/margaret-thatcherat-the-famous-photoshoot-riding-in-a-tank-1986-1986-image7456496.html (all accessed 31 May 2019). ${ }^{15}$ The Nigel Farage image is available at Channel 4 Election News (4 April 2015), 'Ruth Davidson on a Tank', https://news.channel4.com/election2015/04/29/update-4401/ (accessed 31 May 2019). The comparison with Davidson's image is striking.

${ }^{16}$ The van on which the design appeared belonged to alleged bomber Cesar Sayoc, though the artist himself claimed to be apolitical (Stephen 2018).
} 
of gender in what she called 'an integral connection between two propositions': 'gender is a constitutive element of social relationships based on perceived differences between the sexes', and 'gender is a primary way of signifying relationships of power'. ${ }^{17}$ Maleness and femaleness are, she argued, vested in particular symbols that can be interpreted in different ways across different cultures. '[F]or historians ... the interesting questions' are both what 'symbolic representations are invoked, how, and in what contexts', ${ }^{18}$ and how cultures 'attempt to limit and contain [the] metaphoric possibilities' of such symbols. The historian's goal must thus be not only to uncover the meaning of masculine and feminine within a given society, but to 'disrupt the notion of fixity' that so often surrounds these categories. ${ }^{19}$ For Scott, then, gender is both object and tool: simultaneously the object of scholarly inquiry, and the means by which institutions like nation and household, or concepts like time and place, can be productively explored.

Historians of pre-Conquest Wales are only just beginning to take up Scott's challenge. The field of women's history per se is extremely vibrant, with accomplished scholars writing on a rich variety of topics. ${ }^{20}$ However, with a few outstanding exceptions ${ }^{21}$ most of the work published to date on gender has been largely post-Conquest in focus: there is little as yet to match the outpouring of works on medieval masculinities and femininities that we have for the European continent. ${ }^{22}$ My hope in this article is to take some initial steps in that direction. I have written on some aspects of this topic before. In a book published in 2018, I argued that gender was one of the principal 'languages' used by the lawbook authors to comment on controversial issues. The tractate on the court, for example, with which the lawbooks open, deliberately situates the queen as separate from political affairs, remaining apart from the court in her chamber while the king moves freely across all spaces in the household. This runs completely contrary to the historical evidence and is likely intended as a critical commentary on Llywelyn the Great's queen Joan, who participated actively in Welsh

\footnotetext{
${ }^{17} \operatorname{Scott}(1986: 1067)$.

${ }^{18} \operatorname{Scott}(1986: 1067)$.

${ }^{19} \operatorname{Scott}(1986: 1067)$.

${ }^{20}$ Burton (2015); Cartwright (1997, 2002); Cavell (2007a, 2007b, 2014, 2015); Fulton (1991); Jenkins \& Owen (1980); Johnson (2009, 2013, 2014); Lloyd-Morgan (1993, 1998, 2000); Powell (2000); Richards (2009); Roberts, S. E. (2011); Smith, J. B. (1982-83); Smith, Ll. B. (2000); Youngs (2012).

${ }^{21}$ Works on the pre-Conquest period include: Johns (2013); Patterson (1988); Stacey (2002). Immediately post-Conquest in focus is Stevens (2010). See also on this topic Chandler (2002) and the theses by Kapphahn (2009) and Chandler (2004). For the Early Modern period, see Roberts \& Clarke (2002), and articles by Deborah Youngs \& Nicola Whyte in Kane \& Williamson (2013).

${ }^{22}$ A representative sample would include: Bennett \& Karras (2003); Erler \& Kowaleski (2003); Hadley (1999); Karras (2003); Lees (1994); Romig (2017); Sauer (2015); Stafford \& Mulder-Bakker (2002); Stone (2012); and Van Dijk \& Nip (2005). An up-to-date (to 2018) bibliography can be found in Skinner (2018).
} 
political affairs even after her notorious affair with a Marcher lord. ${ }^{23}$ Similarly, what purports to be a description of the equitable division of household goods by divorcing spouses ought in fact to be read as a hostile and highly gendered commentary on the native Welsh practice of permitting divorce, which by this date was forbidden to European Christians by the church. ${ }^{24}$ And the deliberate depiction by the jurists of royal tax collectors and other unpopular officials as visibly effeminate in their body, clothing, and equipment was intended, I argued, as a pointed critique of the increasingly intrusive nature of the prince's rule. ${ }^{25} \mathrm{My}$ intention in the present essay is to build upon these arguments and images by turning them the other way around, as it were, and focusing specifically on gender in the hope of understanding how it constructs, and is constructed within, the imaginaries of the lawbooks.

\section{The court}

There can be no better place to begin than with the very first venue we encounter in the lawbooks, the royal court, which is described in the laws through a list-like accounting of the duties and privileges of the officers who serve the king's household. From this we learn about the physical layout of the household, the mutual responsibilities tying the officers to their lord and to one another, the duties of these officers, and their places in the hall. The latter is the context in which Rhŷs' remarks about the queen and other court ladies were made. As mentioned earlier, it is extremely unlikely that these women would historically have been missing from the events attendant on the three great feasts. Rather, as I have argued elsewhere, their imagined absence from these festivities is part of a deliberate textual strategy designed to portray courtly politics as exclusively male. This is why the queen and her female servants are depicted as largely relegated to bed chamber and kitchen, separated from the political space of the hall. It is also why they are the only women referred to at all at court and that no wives or other female guests are mentioned. ${ }^{26}$ Indeed, the very first paragraph in the Book of Iorwerth court tractate directly opposes the 'officers of the queen' to the 'officers of the court' in a way that makes clear that 'queen' and 'court' are to be considered separate categories. ${ }^{27}$

\footnotetext{
${ }^{23}$ Stacey $(2000,2018: 65-73,150-67)$. Nor was Joan's involvement likely the only one to which the jurists objected (Cavell 2014, 2015, Johns 2013).

${ }^{24}$ Stacey $(2002,2018: 150-67)$.

${ }^{25}$ Stacey (2018: 91-148).

${ }^{26}$ Stacey (2002: 53-62, 2018: 65-73).

${ }^{27}$ Llyfr Iorwerth, hereafter cited from Wiliam's edition as Ior. References are to paragraphs and sentences unless indicated otherwise (Ior, 2/1-3 and compare with 22/1).
} 
In short, what we have in the Laws of Court tractate is a description not of the king's household as it actually was, but of the Welsh court and polity as the jurists wished them to be: gendered solely as male and free from the pernicious influence of women like Joan. But, just as gender considerations helped to shape the court, so also must the court as depicted in these critical texts have helped to construct and disseminate notions about gender. The main point of the passage to which Rhŷs drew our attention was actually to identify the fourteen male officers occupying special chairs in the court during formal feasts (Ior §5). In other words, this was first and foremost a passage on status intended to delineate the ranks of male officials serving the king. However, in context it functions also as a passage on gender: one that serves not only to identify the court as a political space into which women do not enter, but implicitly defines femaleness with respect to political matters as a condition of absence rather than presence. ${ }^{28}$

This equation of the female with absence - in this case from the physical space of the court and, by extension, the polity it symbolises - is underscored in the text by women's concomitant exclusion from courtly time. The cultural parsing of time is not itself an ideologically neutral act. A common perception in the middle ages, for example, was that time belonged to God-an idea rendered tangible in the shaping of the monastic day. ${ }^{29}$ Similarly, the rewriting of clock and calendar during the French Revolution was intended as an explicit rejection both of the Old Regime and of Christianity. ${ }^{30}$ Equally ideological, I would suggest, is the manner in which time is defined in the Laws of Court tractate, where the passing of the year is deliberately measured almost entirely with respect to courtly events. Front and centre are the three great religious feasts of Christmas, Easter, and Whitsun. These are religious holidays first and foremost, but they appear in the lawbooks largely as courtly festivals. ${ }^{31}$ It is on these occasions that formal feasts occur, officers receive specialised equipment and clothing, and certain persons are exempted from legal claims by virtue of their jobs. ${ }^{32}$ Even Lent is described in the lawbooks mainly as a court performance, in that at the end of the Lenten season the clothes worn by king and queen during their periods of penance are given to their respective priests..$^{33}$ Other important times mentioned in the

\footnotetext{
${ }^{28}$ Stacey (2002: 53-62, 2018: 65-73).

${ }^{29}$ Le Goff (1980: 29-42); Munn (1992: 109-10); and see Porro (2001) on medieval theories of time generally.

${ }^{30}$ Munn (1992: 110).

${ }^{31}$ For example, Ior 6/14-15; 8/8-9; 9/4-5, 7, 11; 11/7-8, 10; 15/9, 13, etc. For exemption from legal liabilities, see Ior 9/17; and 15/8, 10, 12, for example, and Pryce (2000b: 82).

${ }^{32}$ For example, Ior , 2/4; 4/17; 6/8; 8/4; etc. See also: Stephenson (2000: 409), and for a slightly different emphasis, see Charles-Edwards et al. (2000b: 7) and Charles-Edwards (2000: 323).

${ }^{33}$ Ior $7 / 11 ; 23 / 6$.
} 
court tractate are the seasons of hunting, going on circuit, and training for waragain, all good courtly activities. ${ }^{34}$

A comparison with time as imagined elsewhere in the laws makes clear that the choice to depict the year in this way was deliberate. The Laws of Country and pleading texts mark time according to non-courtly activities like agriculture, which appears in the court tractate only in the context of the taxing by royal officials of the profits thereof. Saints' days similarly appear in the court tractate largely in connection with the hunt, whereas in the Laws of Country, they are often markers for the agricultural year..$^{35}$ This parsing of time is intentional, a fact that is important for our purposes today, because courtly time, like courtly space, is gendered in the lawbooks as almost entirely male. Queens and other women - and it is worth remembering that the queen is the only woman apart from low-status servants mentioned in connection with the court - are depicted as having no role to play in hunting or training exercises and are thus exempted entirely from that manner of measuring time. Even the royal circuit said in two lawbook versions to be taken by the queen is imagined as taking place while the king is away on campaign and thus underscores her peripheral relationship both to courtly time and to the nation's political affairs. ${ }^{36}$

Indeed, the only indication in the text that women participate in courtly time at all comes from the gifts the queen is said to give the king's court officers on ceremonial occasions like the three great feasts. Historically, such gifts would almost certainly have been presented in the hall in full public view. However, in the constructed court of the lawbooks, things are not so clear. ${ }^{37}$ Not only is the queen pictured in these texts as located entirely within her chamber, her personal officers may have been also, even during ceremonial events. ${ }^{38}$ Like their mistress, none of them possesses a designated seat within the hall, and they are directly termed 'officers of the chamber' in a passage

\footnotetext{
${ }^{34}$ For example, St. John's day and the hunt in Ior 15/8, 10. Usually marked by calends, or the first of a given month or season. Examples of such time markers include the penteulu's circuit in Ior 6/26-28; the penhebogydd in 9/9; the penkynydd in 15/7-19, etc. Jenkins (2000) discusses the hunt in detail.

${ }^{35}$ For example, St. John's day and pigs (Ior 156/14); St. Bride's day and land disputes (Ior 72/4); St. Mary's and cattle law (Ior 156/8); St. Michael's day and goats (Ior 156/11); St. Michael's day and the steward receiving hawks from the falconer (Ior 8/20); St. Curig's Day and the feeding of calves (Ior 127/13); St. Patrick's Day and meadow law (Ior 157/1), etc.

${ }^{36}$ The 'Book of Cyfnerth', Llyfr Cyfnerth (hereafter cited as WML to Wade-Evans' edition Welsh Medieval Law according to page and line number): WML 57.12-13. See also the Latin lawbooks A-E (hereafter cited as $L T W L$ to Emanuel's Latin Texts of the Welsh Law according to version, page, and line number): Lat A 136.39-40; and Charles-Edwards (2000: 323).

${ }^{37}$ Stacey (2000: 53-62; 2018: 65-73 and references there); Charles-Edwards (2000).

${ }^{38}$ Llyfr Iorwerth, the most politically pointed of the lawbook redactions, certainly leaves open this possibility by depicting the queen's officers as functioning either in the chamber or between chamber and hall (Ior §§22-29).
} 
on the feasts. ${ }^{39}$ And as for the queen's gift-giving: the wording of the passages in which it is described leaves open the possibility that she and the recipient of her largesse are being imagined here as actually in different rooms when the gift was bestowed. It was customary in Wales to present courtly gifts by means of a messenger rather than by conveying them oneself; in other words, gifts could certainly have been sent by her from the chamber into the hall. ${ }^{40}$ Alternatively, gifts could have been presented in the chamber itself. The giving of a gold ring by the queen to the household bard, for example, is depicted as the final act in a sequence of events in which the bard has deliberately left off singing political songs to the men in the hall to go sing softly - and apolitically - to the queen and her servants in her chamber. ${ }^{41}$ At the very least, given the consistency with which the Iorwerth tractate relegates the queen to her quarters, it would be dangerous to presume her presence at court festivals from the fact of her being said to give gifts on these occasions. ${ }^{42}$

Absence would thus seem to be the main characteristic of femaleness within the court as the jurists construct it. Not so with men, although for males as well, positioning within the hall serves within the text as a way to talk about proximity to power. ${ }^{43}$ Not all men just by virtue of their maleness move or sit freely there. Indeed, one of the main points of the Laws of Court tractate is to delineate all of the various hierarchies governing this imagined royal space. ${ }^{44}$ The tractate as a whole is devoted to the careful description of the privileges and positioning of the male constituency of the courtwithin the hall, in terms of lodgings, and with respect to the king. ${ }^{45}$ The only male with complete freedom of movement is the king; even the royal heir's movements are circumscribed lest they threaten him. Beyond this, some officers occupy the upper and some the lower precincts of the hall; some are imagined as ranging widely within court and realm and some are not. ${ }^{46}$ One of the basic divides is between the free and the unfree, marked here by the freeman's access to the person of the king. ${ }^{47}$ Maleness in

${ }^{39}$ Ior $\S 5$. The supper money shared out at the feasts is, moreover, divided into thirds, with two-thirds going to the svydwyr e brenhyn, 'the officers of the king', and the other third going to the svydwyr e urenhynes, 'the officers of the queen', who are then later termed in the same sentence the gueyssyon esteuyll, the 'officers of the chamber' (Ior 8/24).

${ }^{40}$ Charles-Edwards (2000: 328-33).

${ }^{41}$ Ior $13 / 4-7$.

${ }^{42}$ The presentation of the ring seems to be depicted as part of the sequence of events described in Ior $13 / 4-7$.

${ }^{43}$ The study of gender encompasses maleness as well as femaleness, albeit controversially in some circles (Weikart \& Woodacre 2016: 2).

${ }^{44}$ Scott herself came to gender history through an earlier awareness of the constructed nature of class and class action (Scott 1974). See also Plumauzille (2014) and Weikart \& Woodacre (2016).

${ }^{45}$ Ior $\$ \S 1-41$.

${ }^{46}$ Charles-Edwards (2000: 323-8); Stacey (2000: 338-46; 2018: 56-88).

${ }^{47}$ Charles-Edwards (2000: 327). 
this text is thus a sine qua non for entry into the political space, but it is not in itself a guarantee of access or franchise. On the other hand, men are imagined as present in a way that women are not. Even younger and lower status male officers are cast as rightful occupants of a courtly landscape from which women are largely absent. Indeed, the only place in the lawbook where a male body disappears altogether shows the extent to which status and gender hierarchies are imagined as overlapping in this text. When a freeman is attacked or killed, he or his relatives receive other bodies - cattlein compensation for the offence. When a slave is killed, by contrast, his kindred receives only the few pennies it takes to replace his clothing and tools; his body, like those of the women in the court, simply disappears altogether. ${ }^{48}$

What is true of the lawbook's depiction of the physical space of the court is true also of time. Apart from the queen's male servants, whose presence or absence cannot be determined from the text - if they are absent, this would truly be an exception that proves the rule ${ }^{49}$ - all principal male officers are depicted as either exercising their office at the three feasts or as possessing designated seats in the feasting hall. Even those officers who, like the steward, do not have seats in the court, are clearly envisaged as part of its royal display; in other words, their seat-lessness is anything but a sign of absence or erasure. ${ }^{50}$ Similarly, all male officers play a role also in the yearly court calendar of hunting, campaigning, and seasonal court dispersals, when the warband, huntsmen, and grooms went on circuit and were billeted on subject households..$^{51}$ In real life, queens and other women would surely also have been integrated into this seasonal rhythm in various ways. ${ }^{52}$ However, in the lawbooks they are portrayed as essentially peripheral to it. The queen's circuit, unlike those of the male officers, is conceptualised as occasional, something that might occur when the king himself had a need to be elsewhere, and thus not part of the normal courtly routine. The circuits of the royal officers, by contrast, not only form part of the courtly calendar, but constitute perquisites of those officers' positions. They are, in other words, an extension of the court and court time rather than a removal from it $-\mathrm{a}$

\footnotetext{
${ }^{48} \operatorname{Ior} \S 110$.

${ }^{49}$ Ior $\$ \$ 22-29$.

${ }^{50}$ It was customary on ceremonial occasions for offices performed during the year by underlings to be undertaken by the officer himself as a public performance of loyalty and proximity to the king's person. This is almost certainly true of the distain or steward, for example, who is imagined as actually serving at the feast, and was probably true also of the usher and doorkeeper of the hall (Ior 5/3). The distain was historically by the 13th century the king's chief minister and principal agent (Stephenson 1984: 11-20, Smith J. B. 1972: 34). He appears in the laws, however, in his earlier historical capacity as the officer in charge of food and drink.

${ }^{51}$ Charles-Edwards (2000: 322-3); Ior 2/26-29 and 92/3; WML 57.15-17; 18.11-12; 19.13-15; LTWL Lat A $136-7$.

${ }^{52}$ Stacey (2000: 60-1).
} 
point underscored for the captain of the warband by the fact that he is described as being served while on circuit much as the king himself would have been. ${ }^{53}$

Another aspect of the gendering of the court is its use of body imagery. We learn nothing about the female body per se since, as we have seen, it is largely absent. We do learn about ideas regarding female and maleness, however, from the manner in which the bodies of unpopular male officials are depicted. As mentioned earlier, the laws mirror complaints found in non-legal writings of the period about the increasingly arbitrary and oppressive exactions of the Welsh princes. Certain royal officials were especially unpopular, and the jurists found inventive ways to communicate their contempt for them and their actions. ${ }^{54}$ One strategy was to call their physical masculinity into question by depicting them as female or childlike. Most memorable of all is the rhingyll or sergeant, whose job it was to keep order in the community by summoning offenders to court and collecting fines. The clothing he is described as wearing - a short little tunic made of linen rather than wool, ${ }^{55}$ short booties reaching only to the ankles rather than boots, a heavy coat in summer and a light cape in winter-constructs him as childlike, foolish, and female. Linen as a cloth is associated in this text primarily with the queen, who provides linen to every court official, and it was customarily worn as underwear. Outerwear - the livery that marked an officer's connection with the court - was made of wool and bestowed by the king. ${ }^{56}$ One has only to visualise the stains that might accumulate on an exterior linen garment as its wearer moves from farm to farm in the course of his duties to get the point.

The feminising of the sergeant is visible also in the rewards he receives for enforcing royal claims to property for which there is no immediate male heir. These are items that elsewhere in the lawbook are explicitly associated with the goods that women divorcing their husbands take away from their broken union: butter that has been already cut open, the lower stone of a quern, small scrubby grain, a small hand-axe, and hens. Many of these function in the divorce passage as a symbol of the size and weakness of the woman receiving it. Some, however, are pointedly obscene, such as the broached and no longer virginal butter and, probably, the lower quern stone as well, as it occurs in the divorce passage right before a sentence on the dividing up of the bedclothes and seems likely in context to be a reference to the person taking the passive role in a sexual encounter. ${ }^{57}$ Very similar is the payment the sergeant is said to receive in compensation for an offence committed against him in court-a sieve of

\footnotetext{
${ }^{53}$ Ior 6/26-29.

${ }^{54}$ The argument that follows summarises in short form conclusions reached in Stacey (2018: 114-27).

${ }^{55}$ Most say without tenllif, 'mixed fabric, linsey-woolsey' (the Latin texts often specify 'in his pants'); Llyfr Cyfnerth says directly that they are to be made of linen (WML 30/3-6).

${ }^{56}$ Stacey (2018: 114-27).

${ }^{57}$ Ior 44/8-9; Stacey (2002).
} 
chaff and an addled egg, which latter neatly constructs him as a sitting, though unproductive, hen. Worst of all is the spear he is described as using in his policing duties, which is characterised as unusually short and held with most of the length of the spear behind him. A contemporary lawbook illustrates the scene: not only is the business end of his spear abbreviated and grasped in both hands with disturbingly elongated thumbs prominently displayed, it passes directly through his groin at an angle unlikely to be of much use in war. Other despised royal officials are also associated in this text with short sticks or beasts with short tails, or even with the rectum. ${ }^{58}$ Worth noting also is the case of the cleric who, along with women, old men, and young children, is said not to pay the 'spear penny' owed by all male relatives of a destitute killer. Women do not pay this because they 'do not have a spear but only a distaff'. ${ }^{59}$ Nothing specific is said about the spears of clerics, old men, and young boys, but the implication is obvious.

I am not of course suggesting that this is an accurate depiction of the sergeant. Rather, these are derisory payments designed to mock him and, more significantly, the prince he serves by constructing their excessive exactions as unmanly and harmful to the prosperity of the union between prince and nation. However, these passages tell us a great deal about gender as the jurists envisaged it. It is surely no accident that those articles of clothing most closely associated with a noble male courtier are those most directly targeted in the sergeant's description: the livery that is a marker of his courtly service, the boots and weapons that are signs of his manhood and status. Nor is it accidental that his body is described as it is. Absence is an attribute of femaleness in this tractate, and his spear, while not missing, is clearly not everything it could be. In deriding the sergeant by impugning his maleness, the jurists are both drawing on and perpetuating cultural assumptions about gender. That which is male in courtly circles is intrinsically linked to status, royal service, and wholeness in both dress and person. That which is female is linked through the queen to seclusion and absence, and through the sergeant to childishness (the boyish clothes and short spear), sexual dishonour or impropriety (the broached butter, publicly worn underwear, and quernstone), and the transgression of acceptable political norms (the sergeant's exactions themselves). Scott urges us to identify the symbols that cultures employ to talk about gender, and the manner in which the 'metaphoric possibilities' of those symbols acquire the appearance of fixity in a given historical context. The images we have been examining provide us with a glimpse of a mechanism through which fixity of this sort can be asserted. It is surely no coincidence that they appear in the opening tractate of what contemporaries regarded as a national lawbook.

\footnotetext{
${ }^{58}$ Stacey (2018: 114-27).

${ }^{59}$ Ior $106 / 10-11$.
} 


\section{The country}

In passing from court to country, we encounter a whole new set of gender associations and imagery, albeit one connected in some ways to what we have seen already. The Laws of Country consist of a number of tractates, some short, some long, on subjects such as homicide, theft, and arson; suretyship; land rights; and wild and tame animals. Amongst these is a lengthy tractate called the Laws of Women which, as might be suspected from the name, focuses specifically on what the jurists identify as women's issues. Among these are women's personal and property rights upon marriage or separation, redress for rape and abuse, penalties paid in respect of sexual transgressions, and rights to child-maintenance. ${ }^{60}$ Women are even said to be able to separate from their husbands if his breath is too smelly to be borne. ${ }^{61}$ It is clear from this text that in some respects Welsh women enjoyed rights that many women elsewhere in Europe did not. However, there were restrictions as well. Unlike English women, for example, Welsh women were not permitted to inherit land under native law, even in instances in which their fathers wished them to; nor were they entitled to dower lands upon being widowed. ${ }^{62}$ We know from elsewhere that these restrictions were changing in the period of the lawbooks under influence from English and Marcher inheritance customs, and that indeed by the end of the middle ages, native women would enjoy much the same rights to land as their English counterparts. ${ }^{63}$ However, the lawbooks in their role as imaginaries give little indication of these developments. ${ }^{64}$

The inclusion in the lawbooks of an entire tractate on women is itself evidence that the jurists imagined women and the female as being part of the country in a way they were not of the court. This may be because, for the lawyers, court and country mapped directly to that of ruler and ruled: in their view, women were included amongst

${ }^{60}$ The Welsh Law of Women provides editions with translations of several of the major texts along with scholarly essays on the subject of women generally.

${ }^{61}$ Ior 45/4.

${ }^{62}$ Only one legal text permits this, and then only when no male heirs existed. The latter provision was almost certainly influenced by Common Law practice: Llyfr Blegywryd (hereafter cited as Bleg to the edition by Williams and Powell Cyfreithiau Hywel Dda yn ôl Llyfr Blegywryd according to page.line number): 75.24-25. Contrast Ior 86/1 and Llyfr Colan 600 (hereafter cited as Col to Dafydd Jenkins' edition Llyfr Colan according to numbered sentences). Also useful are Jenkins (1980a: 75); and Davies (1980).

${ }^{63}$ In fact, the willingness of the Welsh princes to abandon native custom in favour of English practices when it suited them was one of the main complaints brought against them as rulers (Pryce 2007: 41). See also on these changes, Smith, Ll. B. (2000); Cavell (2007a, 2007b, 2014); Richards (2009); Roberts, S. E. (2011); Smith, J. B. (1982-83); Mitchell (2003: 57-77); and Swett (1995).

${ }^{64}$ The sole exception in the lawbooks is Bleg 75.24-25, which allows Welsh women to inherit if there were no male heirs. Landowners without sons often attempted to adopt English practices in order to prevent their estates from being broken up and dispersed among distant male relatives (Davies 1980: 100-1). 
the prince's subjects in a way they could never be amongst his peers. However, at least one of the principal manuscripts of the lawbook version on which we are focusing seems to call even this into question. ${ }^{65}$ For in it, the Laws of Women are not presented as part of the Laws of Country but, rather, appear in between the Laws of Court and the Laws of Country as a separate lawbook section all on their own. ${ }^{66}$ All indications are that this placement was likely not original to the earliest lawbooks, or even to the Book of Iorwerth as originally composed. On the other hand, the redactor obviously intended to reposition the Laws of Women in this way, since he signposts the beginning and end of each section in a manner that clearly differentiates one from the other. The effect is structurally to separate women from both court and country in a way that suggests that they belong to neither one: the female appears as contingent both to the court and to the realm over which the court rules. ${ }^{67}$ And in truth, something of this sort would seem to be implied even in the more usual arrangement. After all, there is no tractate on the Laws of Men: all laws are men's laws. The only groups other than women to be set apart in separate discussions of their own are children, animals, and, to a less focused degree, foreigners. ${ }^{68}$

The notion of contingency may in fact be a helpful way to think about femaleness as it is depicted in the Laws of Country generally. As presented in the laws, the landscape outside the court is comprised largely of the lands and fields worked by those ruled by the occupants of the court. Almost a third of the lawbook focuses on farming, land claims, and land divisions, and another tenth or so on farm equipment and animals. This is true also of the pleading texts, where almost all the pleadings in one manuscript, and a decent portion of another, are taken up with similar matters. ${ }^{69}$ Now, Wales was a largely agrarian economy in the period, so this emphasis is not wrong; moreover, it seems likely that the balance of pleadings does reflect the nature of the disputes heard most frequently in court. However, this picture, while not erroneous, is at best incomplete, as it ignores entirely the tremendous social and economic changes taking place at the time the laws were being written. Not mentioned at all, for example, are the Marcher lordships with their powerful seigneurial lordships, increasingly hybrid customs and loyalties, and rapid urban growth. Also left out are the hostilities with England that were ultimately to lead to the extinction of native

\footnotetext{
${ }^{65}$ Llyfr Iorwerth manuscript B = London, British Library, Cotton Titus D. ii of the thirteenth century.

${ }^{66}$ Ior 44/1; 55/16; 56/1.

${ }^{67}$ Stacey (2018: 131-5). Given the variation in where in the lawbook the tractate is found, Jenkins suggests that it was floating (Jenkins 1980b:135; see also Russell 2005: 61-2, Charles-Edwards 1980: 27-9). A. R. Wiliam believed manuscript B's to be the original location (Ior, xxi-xliv, and see Col 68, which marks an explicit end to the Laws of Women but says nothing about that text's relationship to the Laws of Country).

${ }^{68}$ Ior $\$ \$ 97-103$ and 121-37, and see references to alltud, 'foreigner, alien', in Ior, 143.

${ }^{69}$ Books VII and VIII, respectively, of the pleadings in the Ancient Laws of Wales.
} 
Welsh independence in 1282-84. Even changes taking place within native Wales itself, such as the rapid expansion of the economy and the gradual emergence of markets and towns, pass largely unremarked in the lawbooks - a fact which, if nothing else, again underscores the 'imaginary' element of this particular social imaginary. ${ }^{70}$

Women were obviously a part of this agrarian landscape as the jurists depicted it. The Laws of Women passage on divorce envisages husband and wife dividing up the utensils and products of their joint household in a way that clearly presumes that both have contributed fruitfully to the marital economy. However, the real focus of the Laws of Women is not production or labour but, rather, male/female sexual relationships and their short-term and long-term social and economic consequences: specifically, the dues, rights, obligations, and procedures that come into play when a sexual relationship is planned or initiated. Not that women are imagined as carrying all of the burden in such matters. Men as well as women are described in the text as experiencing consequences for their sexual behaviour. ${ }^{71}$ However, it is striking that sexual liaisons and their financial repercussions - licit or illicit—-would seem here in the laws to be gendered as female, the only and appropriate focus for a text calling itself the Laws of Women. Even the short tractate on children and family law, which occurs well outside the Laws of Women, is an exception that proves the rule. For its focus is the affiliation of sons to the kindred and ensuring the proper male line and these, as we shall see, are issues that the jurists gender as male. ${ }^{72}$

Equally significant is the fact that femaleness is presented as being largely to do with sexual unions and their consequences. The mere existence of a Laws of Women tractate focused on sexual unions need not necessarily mean that this is the only sphere in which women could be imagined as operating. However, apart from the queen in her chamber - itself a symbol of properly deployed sexuality - that is exactly the impression given here. Were it not for the Laws of Women tractate, women would hardly appear in the laws at all; as it is, their out-of-tractate appearances are either to do with legal restrictions upon them, payments made to or by men in respect of them, and their role in transmitting land-rights to their male heirs. ${ }^{73}$

The contrast with men and maleness is evident. Masculinity is defined in a variety of ways throughout the lawbook, including many we have seen before with respect to the court, such as status, proper comportment in rank, and wholeness of person

\footnotetext{
${ }^{70}$ Davies (1987: 37-9, 157-71, 271-88, 2000: 142-71); Fulton (2012).

${ }^{71}$ Ior $\$ \$ 44-55$.

${ }^{72}$ It is no accident that the section that precedes it has to do with land administration and the collection of royal food renders from subordinate households. See Ior $\$ \$ 44-55$ for the Laws of Women, and $\S \S 97-103$ on children (following $\S \S 91-96$ on land).

${ }^{73}$ Ior $\$ 86$ (women and land); $\$ 106$ (galanas, murder and compensation); and $\$ 110$ (sarhaed committed against them). Ior $\$ \$ 97-103$ is the family law section.
} 
and appearance. One thing that may strike those familiar with scholarship on medieval European concepts of gender as surprising is the relative paucity of references to war, either in a leadership or follower role. Almost every major gender study known to me has one or more chapters on what Ruth Mazo Karras calls 'mail-(in the sense of armour)-bonding' ${ }^{74}$ In the Welsh lawbooks, however, court service and farming rather than war are the venues with which masculinity is associated, despite the many wars in which the Welsh were engaged during this period. This relative downplaying of military matters seems likely to be deliberate and may be a response by the jurists to contemporary accusations of violence and disunity made against the Welsh. Certainly, an account of maleness written on the basis of the poetry of the period rather than the laws would return very different results. ${ }^{75}$

In the Laws of Country, however, the most important markers of masculinity are seen in images pertaining to farming and the patrimony. The pleading texts particularly evoke narratives of long-time occupation and the fruitfulness of a land farmed over the generations from father to son in stable succession. Litigants declare themselves to be occupants of a given land for 'years and years with house and chattels and tilth and ploughing'. ${ }^{76}$ Those claiming hereditary right to a given parcel of land enter onto it and are allowed to farm without hindrance until they have 'turned their back on the haystack' - a performative action marking the end of the harvest that underscores the legitimacy of their claim by linking it both to the fertility of the land and to the rhythms of the agricultural year. ${ }^{77}$ As in many world cultures, one of the most important symbols used by the jurists is the hearth, which functions in the laws both as a physical reality and a metaphor for rightful transmission through the paternal line. One of the early methods of claiming patrimonial land-discussed still at length in the 13th-century lawbooks - was dadannudd, the public uncovering of the paternal hearth by an heir seeking literally and figuratively to rekindle his right to the ancestral holding. ${ }^{78}$ The hearthstone of a father, grandfather, or great-grandfather could be used as evidence of a man's claim to land. ${ }^{79}$ But most telling of all from the gender

\footnotetext{
${ }^{74}$ Karras (2003: 2-66); Stone (2012: 69-115); Hadley (1999: 39-55, 71-88); Skinner (2018: 131-9); and compare Romig (2017).

${ }^{75}$ Suppe (1989); Johnson (2008); Stacey (2018: 183-211); Chandler (2004); and Kapphahn (2009).

${ }^{76} A L W$ VII.i.23, 27.

${ }^{77}$ WML 49.1-3; Ior 84/3; ALW VII.i.27.

${ }^{78}$ Originally an elaborate ritual involving formally timed entries onto the land in question as well as the uncovering of the paternal hearth, dadannudd was undergoing significant changes in the period of the lawbooks, but its symbolism was still understood. See Ior \$84; see also discussion in Charles-Edwards (1993: 274-303) and, on the Irish tellach, Charles-Edwards (1993: 259-73).

${ }^{79}$ WML 136.17-137.2. The covering and uncovering of a hearth played a role also in determining whether an unmarried woman who is slept with outside of marriage was entitled to compensation. If the couple retired before the fire was covered over at night and rose after it had been lit in the morning for three
} 
point of view is the fact that men can themselves be referred to as hearths. The word hearth (aelwyt) is used in the laws to refer to male members of a kindred, ${ }^{80}$ just as the word dadannudd is used in another passage to refer to a male who claims land by inheritance ${ }^{81}$ The Laws of Court even make use of this symbol when they speak of the king's heir sleeping at night by the royal hearth surrounded by youths who will someday constitute his own retinue. ${ }^{82}$

This connection of maleness with land and hearth reflects in large part stages in the life-cycle of each sex, the main transitional moment for a male being entry into his inheritance and for a female the loss of her virginity. ${ }^{83}$ Women are never referred to as hearths or included in the language or seasonal rhythms to which these pleas make appeal. And while this might merely be the logical outcome of the prohibitions against female inheritance, I think there is more to it than that. Hearth and land are part of a much broader vernacular in the laws linking the fertility of the land and the continuity of the paternal kindred to matters of gender and sexual propriety. For when women are mentioned in the laws in connection with land, it is in a manner that implies infertility and sterility rather than the opposite. A woman who, for example, engages in illicit sexual activity with a man to whom she is not married is termed a 'woman of bush and brake'. The image here is of a couple conducting their shameful business in the bushes or marshy land (brake) away from the prying eyes of those who would prevent the liaison if they saw it happening. ${ }^{84}$ Significantly, the expression 'bush and brake' is used only of the female of the pair; a man can be the son of a 'woman of bush and brake', but he is not of bush and brake himself..$^{85}$ This likely reflects to some degree the differing behavioural expectations attendant on each gender: it was important for women to be virginal upon marriage, but not so for men. ${ }^{86}$ But again, the symbolism here runs even deeper. For the woman and her kindred, such a union could

nights in a row, the woman was entitled to at least some payment by the man. Part of the point here is publicity - the fact that others are awake to see them. But part of it also may be that the successive covering and uncovering of the hearth over three days gives her a symbolic claim against the wealth of the man's kindred - though not, of course, against its land (Welsh Law of Women, Lat A 51/14, 148-51; and see discussion by Jenkins 1980a: 80-1).

${ }^{80} \mathrm{~A}$ father, older brother, or father-in-law (WML 135.12-17).

${ }^{81}$ LTWL Lat A 130.18-131.5; Charles-Edwards (1993: 274-5).

${ }^{82}$ Ior $4 / 4$.

${ }^{83}$ Charles-Edwards (1993: 175-81).

${ }^{84}$ G6reic l6yn apherth/mulieris lluyn et perth, 'a woman of bush and brake' (Ior 49/1, WML 129.6-7, 61.21, 62.3, $L T W L$ Lat B 244.39, Lat D 372.3-4, ALW VI.i.59, for example).

${ }^{85}$ WML 127.25, mab agahat kyn no ef yn ll6yn apherth, is the exception that proves the rule, in that his 'taint' is not imagined as organic to him and could be overcome by the father accepting him. In the woman's case, the taint becomes a part of herself-who she now is - and cannot be overcome. See also the mab agahat of $W M L 128.3-4$; compare 52/7.

${ }^{86}$ Ior 47/5; McAll (1980: 9). 
never prove productive or fertile because she is ruined for another match. She has become, quite literally, herself 'bush and brake', a field that can no longer be productively 'ploughed'. Even had she conceived a son in the act, she would rear him only for a year before turning him over to the father as primary caretaker. Acknowledged illegitimate sons inherited equally in Welsh law with their legitimate brothers, so from the perspective of the father and his kindred, the seed that impregnated her had fallen on fertile ground. ${ }^{87}$ Not so for her.

Similar ideas about women, fertility, and land are visible elsewhere in the laws. Women who divorce or are widowed get the flour and prepared goods symbolic of the fertility of the union they have enjoyed up until then. However, they are explicitly denied the seed-corn with which to produce future grain themselves. ${ }^{88}$ The only exception is women who are pregnant, ${ }^{89}$ who receive corn in order to support the child. However, this too is an exception that proves the rule, since children are legally treated as potentially male until they are baptised..$^{90}$ What we are looking at here is a complex conjunction of symbols and ideas involving gender, sexuality, and the land. Sexual liaisons and their consequences might be gendered as female in the laws, but fertility and the future are gendered as male. Males alone possess the seed that ensure that kindred will continue, the hearth will be kindled, and the land will continue to bear fruit. Women are more akin to the field in which that seed has been planted: either legitimate and fertile, or bush and brake in both senses. Even ideas about animals reflect similar notions. One lawbook defines the main characteristics of female birds as laying and hatching, and those of male birds as impregnating and singing about it afterwards. ${ }^{91}$ The female bird, like the land, may receive and incubate the seed given to her in order to bring forth the next generation, but she is imagined as a receptacle into which that generation has been planted rather than as a creatrix in her own right.

This emphasis on insemination is visible also in the manner in which status and gender are pictured as overlapping. As with the court, maleness in the country is a sine qua non for farming the land, but it is not in itself a guarantee of full or equal access to land. A key distinction in Welsh law is that between the noble or free man who will

\footnotetext{
${ }^{87} \operatorname{Ior} \$ 47$.

${ }^{88}$ Ior 44/13, 45/1-5, 49/1-3.

${ }^{89}$ Literally 'of weight', gwraig bwys. Wiliam suggests a pregnant woman (Ior, 109), and I have so taken it here. See also the corn received by the woman who rears a child of rape for the first year (WML 98.1-5).

${ }^{90}$ This by analogy to the compensation due a pregnant woman of bush and brake (Ior 97/1-4, CharlesEdwards 1993: 175-6).

${ }^{91}$ WML 79.19-21. Stability of gender can affect franchise as well: a hare has no legal worth because it is male in one year and female the next ( $W M L$ 80.8-10).
} 
one day come into his paternal inheritance, ${ }^{92}$ and the unfree man or villein (taeog), who might or might not inherit property but was bound to his lord and had an entirely different relationship with the land that he farmed. ${ }^{93}$ Several passages make clear just how critical the jurists perceived this distinction to be-indeed, the point is made several times that freemen are inherently closer to princes than to villeins. One of the markers by which such things are measured in the laws is the connection each has with subordinate bodies. A triad included in many lawbooks outlines the 'nets' or economic resources of king, freeman, and villein. ${ }^{44}$ Only kings and freemen are associated with stud animals and the ability to impregnate - the king's stud is superior to that of the freeman, but both king and freeman possess male animals capable of propagating the species. Villeins, by contrast, are imagined as not possessing stud animals at allnot because it would be impossible for someone of villein status to own one but, rather, because status is here being depicted as intrinsically linked to the ability to inseminate. Similarly, it is imagined as inappropriate for villeins to possess animals at all apart from those used for labour; the text says explicitly that even if a villein were to come into possession of, for example, a high-status bird, it would be worth only as much as a hen. ${ }^{95}$ In the latter we see several of the ideas we have been tracing. Villeins are equated with labour rather than leisure, a lack of productivity rather than its opposite (in that hens cannot lay without roosters nearby) and females rather than males. Masculinity, as measured by the ability to engender future generations, is here depicted as a function of status.

One last note regarding the use of body imagery in the text. Physical attributes are obviously important to the jurists. A wife who wishes shame upon the beard of her husband may be beaten without compensation because the beard is a sign of his manhood; ${ }^{96} \mathrm{a}$ girl's legal transition to womanhood is marked in part by the presence of breasts and menses. ${ }^{97}$ But even more telling is the language in which disability is discussed, for there we see the way in which hierarchies of gender, legal capacity, and physical health come together in ways that make them appear to validate one another. Mute men are said to be prohibited from inheriting land or lordship ${ }^{98}$ or receiving compensation for insult because they are, in the words of the text, 'incomplete' ${ }^{99} \mathrm{It}$ is

\footnotetext{
${ }^{92}$ Bonheddig canhwynol. Birth order did not matter in Wales as it did elsewhere, in that native custom adjudged patrimonial lands to the youngest as well as the oldest son, although this too was a native legal principle under attack in the period of the lawbooks (Ior 87/2-7).

${ }^{93}$ Charles-Edwards (1993: 211-15, 364-411, 561).

${ }^{94}$ WML 78.15-16, 20-1, 123.2-14; Ior 42/6-8.

${ }^{95}$ Ior $133 / 1-5,134 / 1-4 ;$ WML 111.14-19.

${ }^{96}$ Ior 51/3; also $A L W$ VI.ii. 148.

${ }^{97}$ Ior $47 / 4$.

${ }^{98}$ Llyfr Cynog in Wiliam (1990: 42.1, pp. 48-9); R. G. Roberts (2013: A801, p. 27, B400, p. 115).

${ }^{99}$ agh6byl: $A L W$ IV.i.7.
} 
impossible to tell from the text whether such men would have been considered incomplete in their maleness as well as in the extent of their franchise, though such seems likely from the fact that wholeness of body is said elsewhere to be a defining characteristic of maleness for both men and birds. ${ }^{100}$ What is more certain, however, is that women's gender-based legal incapacity is rationalised in the laws by being equated to a male physical disability. In one passage, women are grouped with mutes and foreigners who cannot speak the language as persons for whom legal advocates must be appointed; ${ }^{101}$ in another, women's legal standing with respect to testimony is equated to that of liars, foreigners, children, and the blind. ${ }^{102}$

That equivalences of this sort should exist is not in the least surprising. By virtue of its perceived rootedness in nature and theology, gender was one of the most potent languages through which medieval Europeans articulated and validated hierarchies of all kinds — not just status and health, but ethnicity, sexual propriety, and the like. This is why so many scholarly accounts choose to speak of 'femininities' and 'masculinities' in the plural: there exists no single characterisation that can adequately capture the true complexity of the situation. ${ }^{103}$ Knowing what to do with clerics is an especially common dilemma, one which, as we have seen, the Welsh faced as well. ${ }^{104}$ What I hope has become clear in this essay is that cultural ideas about female and male can shape even texts such as law which, on the surface, might appear to have nothing to do with them. The process by which 'politics constructs gender and ... gender constructs politics' ${ }^{105}$ is anything but straightforward, but it repays exploration. Rhŷs may not have realised how 'imaginary' the queen-less court depicted by the jurists actually was, but he was quite right to wonder where the ladies had gone.

\section{References}

Ash, K. M. (2012), Conflicting Femininities in Medieval German Literature (Abingdon and New York, Routledge).

Bennett, J. \& Karras, R. M. (eds) (2013), The Oxford Handbook of Women and Gender in Medieval Europe (Oxford, Oxford University Press). https://doi.org/10.1093/oxfordhb/9780199582174.001.0001

Burton, J. (2015), 'Medieval Nunneries and Male Authority: Female Monasteries in England and Wales', in J. Burton \& K. Stöber (eds) Women in the Medieval Monastic World (Turnhout, Belgium, Brepols), 123-43. https://doi.org/10.1484/M.MMS-EB.5.107544

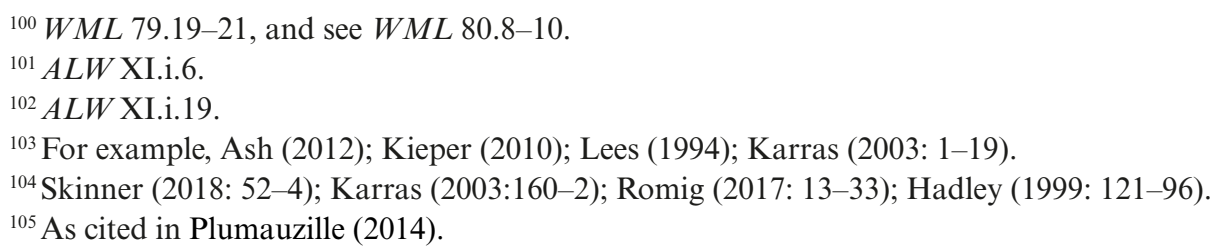


Butler, J. \& Weed, E. (eds) (2011), The Question of Gender: Joan W. Scott's Critical Feminism (Bloomington, IN, University of Indiana Press).

Cartwright, J. (1997), 'The Desire to Corrupt: Convent and Community in Medieval Wales', in D. Watt (ed.) Medieval Women in Their Communities (Cardiff, University of Wales Press), 20-48.

Cartwright, J. (2002), 'Dead Virgins: Feminine Sanctity in Medieval Wales', Medium AEvum, 71(1): 1-28. https://doi.org/10.2307/43630386

Cavell, E. (2007a), 'Aristocratic Widows and the Medieval Welsh Frontier: The Shropshire Evidence', Transactions of the Royal Historical Society, 6th Series, 17: 57-82. https://doi.org/10.1017/S0080440107000539

Cavell, E. (2007b), 'The Burial of Noblewomen in Thirteenth-century Shropshire', in B. Weiler, J. Burton, P. Schofield \& K. Stöber (eds) Thirteenth Century England XI: Proceedings of the Gregynog Conference, 2005. http://www.jstor.org/stable/10.7722/j.ctt81fqv.17 [accessed 24 May 2019].

Cavell, E. (2014), 'Welsh Princes, English Wives: The Politics of Powys Wenwynwyn Revisited', Welsh History Review, 27(2): 214-52.

Cavell, E. (2015), 'Intelligence and intrigue in the March of Wales: Noblewomen and the Fall of Llywelyn ap Gruffudd, 1274-82', Historical Research, 88(239): 1-19. https://doi.org/10.1017/S0080440107000539

Chandler, K. (2002), 'Patriarchy and Power in Medieval Welsh Literature', Proceedings of the Harvard Celtic Colloquium, 22: 80-95.

Chandler, K. (2004), 'Masculinity in Medieval Welsh Literature', PhD Thesis, University of Wales Aberystwyth.

Charles-Edwards, T. M. (1980), 'Relationship of the Tractates in Latin Redactions A and B to those in Llyfr Iorwerth and Llyfr Cyfnerth', in D. Jenkins \& M. E. Owen (eds) The Welsh Law of Women: Studies Presented to Professor Daniel A. Binchy on his Eightieth Birthday 3 June 1980 (Cardiff, University of Wales Press), 180-5.

Charles-Edwards T. M. (1986), 'Cynghawsedd: Counting and Pleading in Medieval Welsh Law', Bulletin of the Board of Celtic Studies, 33: 188-98.

Charles-Edwards, T. M. (1989), The Welsh Laws (Cardiff, University of Wales Press).

Charles-Edwards, T. M. (1993), Early Irish and Welsh Kinship (Oxford, Oxford University Press). https://doi.org/10.1093/acprof:oso/9780198201038.001.0001

Charles-Edwards, T. M. (2000), 'Food, Drink, and Clothing', in T. M. Charles-Edwards, M. E. Owen \& P. Russell (eds), The Welsh King and his Court (Cardiff, University of Wales Press), 319-37.

Charles-Edwards, T. M. (2013), Wales and the Britons, 350-1064 (Oxford, Oxford University Press). https://doi.org/10.1093/acprof:oso/9780198217312.001.0001

Charles-Edwards, T. M., Owen, M. E., \& Russell, P. (eds) (2000a), The Welsh King and his Court (Cardiff, University of Wales Press).

Charles-Edwards, T. M., Owen, M. E. \& Russell, P. (eds) (2000b), 'Introduction', in The Welsh King and his Court (Cardiff, University of Wales Press), 1-9.

Conti, S. (2016), 'Why Everyone is Talking about Theresa May's Shoes', Footwear News, 13 July. https://footwearnews.com/2016/influencers/power-players/theresa-may-prime-minister-fashionshoes-style-239518/ [accessed 31 May 2019].

Cyfraith Hywel website. http://cyfraith-hywel.cymru.ac.uk/en/index.php [accessed 24 May 2019].

Daley, B. (2016), 'Loving Theresa May’s Shoes', The Chicago Tribune, 15 July. http://www.chicagotribune.com/lifestyles/style/sc-theresa-may-shoes-fashion-0718-20160715story.html [accessed 31 May 2019].

Davies, R. R. (1980), 'The Status of Women and the Practice of Marriage in Late-Medieval Wales', in D. Jenkins \& M. E. Owen (eds) The Welsh Law of Women: Studies Presented to Professor Daniel A. Binchy on his Eightieth Birthday 3 June 1980 (Cardiff, University of Wales Press), 93-114. 
Davies, R. R. (1987), Conquest, Coexistence and Change: Wales 1063-1415 (Oxford and Cardiff, Clarendon Press and University of Wales Press).

Davies, R. R. (2000), The First English Empire: Power and Identities in the British Isles, 1093-1343 (Oxford, Oxford University Press).

Douglas, M. (1990), 'The Body of the World', International Social Science Journal, 125: 395-9.

Duby, G. (1982), The Three Orders: Feudal Society Imagined (Chicago, University of Chicago Press).

Dumézil, G. (1968), L’ldéologie tripartie des Indo-européens, Collection Latomus, 31 (Brussels, Latomus).

Dumézil, G. (1979), Mythe et épopée, I: L'ldéologie des trois fonctions dans les épopées des peuples indoeuropéens, Bibliothèque des Sciences humaines (Paris, Gallimard).

Dunn, M. B. (2016), Reviving the Organismic Analogy in Sociology: Human Society as an Organism, University of California_Riverside. https://escholarship.org/uc/item/1179k $78 \mathrm{v}$ [accessed 24 May 2019].

Emanuel, H. (ed.) (1967), The Latin Texts of the Welsh Laws (Cardiff, University of Wales Press).

Erler, M. \& Kowaleski M. (eds) (2003), Gendering the Master Narrative: Women and Power in the Middle Ages (Ithaca, NY, Cornell University Press). https://doi.org/10.7591/9781501723957

Evergates, T. (1997), 'The Feudal Imaginary of Georges Duby', Journal of Medieval and Early Modern Studies, 27(3): 641-60.

Fulton, H. (ed.) (1991), 'Medieval Welsh Poems to Nuns', Cambridge/Cambrian Medieval Celtic Studies, 21: $87-112$.

Fulton, H. (ed.) (2012), Urban Culture in Medieval Wales (Cardiff, University of Wales Press).

Hadley, D. M. (1999), Masculinity in Medieval Europe (London and New York, Longman).

Hess, C. (2013), Social Imagery in Middle Low German: Didactical Literature and Metaphorical Representation (1470-1517), Studies in Medieval and Reformation Traditions, 167 (Leiden, Brill). https://doi.org/10.1163/9789004204959

Huws, D. (1975-76), 'Leges Howelda at Canterbury', National Library of Wales Journal, 19: 340-4.

Huws, D. (1988), Peniarth 28: Darluniau o Lyfr Cyfraith Hywel Dda (Aberystwyth, National Library of Wales).

Jenkins, D. (1980a), 'Property Interests in the Classical Welsh Law of Women', in D. Jenkins \& M. E. Owen (eds) The Welsh Law of Women: Studies Presented to Professor Daniel A. Binchy on his Eightieth Birthday 3 June 1980 (Cardiff, University of Wales Press), 69-92.

Jenkins, D. (1980b), 'Texts of the Tractate on the Law of Women', in D. Jenkins and M.E. Owen (eds), The Welsh Law of Women: Studies Presented to Professor Daniel A. Binchy on his Eightieth Birthday 3 June 1980 (Cardiff, University of Wales Press), 132-35.

Jenkins, D. (1986), The Law of Hywel Dda: Law Texts from Medieval Wales Translated and Edited (Llandysul, Gomer Press).

Jenkins, D. (2000), 'Hawk and Hound: Hunting in the Laws of Court', in T. M. Charles-Edwards, M. E. Owen \& P. Russell (eds) The Welsh King and his Court (Cardiff, University of Wales Press), $255-80$.

Jenkins D. \& Owen, M. E. (eds) (1980), The Welsh Law of Women: Studies Presented to Professor Daniel A. Binchy on his Eightieth Birthday 3 June 1980 (Cardiff, University of Wales Press).

John of Salisbury (1990 edn), Policraticus: Of the Frivolities of Courtiers and the Footprints of Philosophers, ed. and transl. C. J. Nederman (Cambridge, Cambridge University Press).

Johns, S. M. (2013), Gender, Nation and Conquest in the High Middle Ages: Nest of Deheubarth (Manchester and New York, Manchester University Press).

https://doi.org/10.7228/manchester/9780719089992.001.0001

Johnson, L. (2008), 'Mutilation as Cultural Commerce and Criticism: The Transmission, Practice, and Meaning of Castration and Blinding in Medieval Wales', Historia: An Online Graduate History Journal, 1(1). http://depts.washington.edu/cliograd/istoria/Volume_1/contents.html [accessed 3 November 2011]. 
Johnson, L. (2009), 'Attitudes towards Spousal Violence in Medieval Wales', Welsh History Review, 27: 81-115. https://doi.org/10.16922/whr.24.4.3

Johnson, L. (2013), 'Married Women, Crime and the Courts in Late Medieval Wales', in C. Beattie \& M. F. Stevens (eds) Married Women and the Law in Premodern Northwest Europe (Woodbridge, Suffolk, Boydell and Brewer), 71-90.

Johnson, L. (2014), 'Sex and the Single Woman', Welsh History Review, 27(2): 253-81.

Kane, B. \& Williamson, F. (2013), Women, Agency and the Law, 1300-1700 (London, Pickering and Chatto).

Kantorowicz, E. (1957), The King's Two Bodies: A Study in Medieval Political Theology (Princeton, NJ, Princeton University Press).

Kapphahn, K. R. L. (2009), Constructions of Gender in Medieval Welsh Literature, MA dissertation for Aberystwyth University. http://cadair.aber.ac.uk/dspace/bitstream/handle/2160/4637/Constructions OfGenderInMedievalWelshLit.pdf?sequence=1 [accessed 24 May 24, 2019].

Karras, R. M. (2003), From Boys to Men: Formations of Masculinity in Late Medieval Europe (Philadelphia, PA, University of Pennsylvania Press).

Kieper, F. (ed.) (2010), Masculinities and Femininities in the Middle Ages and Renaissance, Arizona Studies in the Middle Ages and Renaissance, 23 (Turnhout, Belgium, Brepols). https://doi.org/10.1484/M.ASMAR-EB.6.09070802050003050209090704

Lees, C. A. (ed.) with Fenster, T. \& McNamara, J. (1994), Medieval Masculinities: Regarding Men in the Middle Ages (Minneapolis, MN, and London, University of Minnesota Press).

Le Goff, J. (1980), Time, Work, and Culture in the Middle Ages (Chicago, IL, and London, University of Chicago Press).

Lloyd-Morgan, C. (1993), 'Women and Their Poetry in Medieval Wales', in C. M. Meale (ed.) Women and Literature in Britain, 1150-1500 (Cambridge, Cambridge University Press), 183-201. https://doi.org/10.1017/CBO9780511582073.011

Lloyd-Morgan, C. (1998), 'More Written About Than Writing? Welsh Women and the Written Word', in H. Pryce (ed.) Literacy in Medieval Celtic Societies (Cambridge, Cambridge University Press), 149-65.

Lloyd-Morgan, C. (2000), 'The Querelle des femmes: A Continuing Tradition in Welsh Women's Literature', in J. Wogan-Brown, R. Voaden, A. Diamond, A. Hutchsion, C. Meale \& L. Johnson (eds) Medieval Women: Texts and Contexts in Late Medieval Britain: Essays for Felicity Riddy (Turnhout, Belgium, Brepols), 101-14. https://doi.org/10.1017/CBO9780511582073.011

McAll, C. (1980), 'The Normal Paradigms of a Woman's Life in the Irish and Welsh Law Texts', in D. Jenkins \& M. E. Owen (eds) The Welsh Law of Women: Studies Presented to Professor Daniel A. Binchy on his Eightieth Birthday 3 June 1980 (Cardiff, University of Wales Press), 7-22.

Mitchell, L. E. (2003), Portraits of Medieval Women: Family, Marriage, and Politics in England 1225-1350 (New York, Palgrave Macmillan).

Moseley, T. (2016), ‘Theresa May's Leather Trousers Prompt Political Row’, BBC News, 12 December. https://www.bbc.com/news/uk-politics-38287637 [accessed 31 May 2019].

Munn, N. (1992), 'The Cultural Anthropology of Time', Annual Review of Anthropology, 21: 93-123. https://doi.org/10.1146/annurev.an.21.100192.000521

Oexle, O. G. (2001), 'Perceiving Social Reality', in B. Jussen (ed.) \& P. Selwyn (trans.) Ordering Medieval Society: Perspectives on Intellectual and Practical Modes of Shaping Social Relations (Philadelphia, PA, University of Pennsylvania Press), 92-143.

Owen, A. (ed.) (1841), Ancient Laws and Institutes of Wales (London, Record Commission).

Patterson, N. (1988), 'Woman as Vassal: Gender Symmetry in Medieval Wales', Proceedings of the Harvard Celtic Colloquium, 8: 31-45. 
Pilcher, J. (2013), 'Margaret Thatcher, 1925-2013: Power, Politics and Gender', Think: Leicester, 15 April. https://www2.le.ac.uk/offices/press/think-leicester/politics-and-international-relations/2013/ margaret-thatcher-1925-2013-power-politics-and-gender [accessed 31 May 2019].

Pithers, E. (2017), 'Theresa May: Building a Strong and Stable Wardrobe', Vogue, 10 May. https://www.vogue.co.uk/gallery/theresa-may-style-analysis [accessed 31 May 2019].

Plumauzille, C. (2014). 'Joan W. Scott's Critical History of Inequality: Revealing Implicit Structuring Norms and Challenging Categories of Difference', Institute for Advanced Study. https://www.ias.edu/ideas/2014/plumauzille-scott [accessed 24 April 2019].

Porro, P. (2001), The Medieval Concept of Time (Leiden, Brill).

Powell, N. (2000), 'Women and Strict-metre Poetry in Wales', in M. Roberts \& S. Clarke Women and Gender in Early Modern Wales (Cardiff, University of Wales Press), 129-58.

Pryce, H. (1986), 'The Prologues to the Welsh Lawbooks', Bulletin of the Board of Celtic Studies, 33: $151-87$.

Pryce, H. (1993), Native Law and the Church in Medieval Wales (Oxford, Clarendon Press). https://doi.org/10.1093/acprof:oso/9780198203629.001.0001

Pryce, H. (1998), 'The Origins and the Medieval Period', in P. H. Jones \& E. Rees (eds), A Nation and its Books: A History of the Book in Wales (Aberystwyth, National Library of Wales in Conjunction with the Aberystwyth Centre of the Book), 1-23.

Pryce, H. (2000a), 'The Context and Purpose of the Earliest Welsh Lawbooks', Cambrian Medieval Celtic Studies, 39: 39-63.

Pryce, (2000b), 'The Household Priest (Offeiriad Teulu)', in T. M. Charles-Edwards, M. E. Owen \& P. Russell (eds) The Welsh King and his Court (Cardiff, University of Wales Press), 82-93.

Pryce, H. (2007), 'Welsh Rulers and European Change, c.1100-1282', in H. Pryce \& J. Watt (eds) Power and Identity in the Middle Ages: Essays in Memory of Rees Davies (Oxford, Oxford University Press), 37-51. https://doi.org/10.1093/acprof:oso/9780199285464.003.0005

Rhŷs, J. \& Brynmor-Jones, D. (1900), 'Ancient Laws and Customs', in The Welsh People; Chapters on their Origin, History, Laws, Language, Literature, and Characteristics (New York, Macmillan), $176-260$.

Richards, G. (2009), Welsh Noblewomen in the Thirteenth Century: An Historical Study of Medieval Welsh Law and Gender Roles (Lewiston, Queenston, and Lampeter, Edwin Mellen Press).

Roberts, M. \& Clarke, S. (2000), Women and Gender in Early Modern Wales (Chicago, IL, University of Chicago Press).

Roberts, R. G. (ed.) (2013), Diarhebion Llyfr Coch Hergest (Aberystwyth, Cambrian Medieval Celtic Studies Publications).

Roberts, S. E. (2011), 'Seeking the Middle-aged Woman in Medieval Wales', in S. Niebrzydowski (ed.) Middle-aged Women in the Middle Ages (Cambridge, D. S. Brewer), 25-36.

Romig, A. (2017), Be a Perfect Man: Christian Masculinity and the Carolingian Aristocracy (Philadelphia, PA, University of Pennsylvania Press). https://doi.org/10.9783/9780812294293

Russell, P. (2005), 'The Arrangement and Development of the Three Columns Tractate', in T. M. CharlesEdwards \& P. Russell (Bangor: Cymdeithas Hanes Cyfraith Cymru), 60-85.

Russell, P. (ed) (2011), Welsh Law in Medieval Anglesey: British Library Harleian MS 1796 (Latin C) (Cambridge, Seminar Cyfraith Hywel).

Sauer, M. (2015), Gender in Medieval Culture (London, Bloomsbury). https://doi.org/10.5040/9781474210683

Scott, J. W. (1974), The Glassworkers of Carmaux: French Craftsmen and Political Action in a Nineteenthcentury City (Cambridge, MA: Harvard University Press).

Scott, J. W. (1986), 'Gender: A Useful Category of Historical Analysis', The American Historical Review, 91(5): 1053-75; reprinted in J. Scott (1999), Gender and the Politics of History (New York, Columbia University Press), 28-52. https://doi.org/10.2307/1864376 
Scott, J. W. (2010), 'Gender: Still a Useful Concept of Analysis?', Diogenes, 57(1): 7-14. https://doi.org/10.1177/0392192110369316

Skinner, P. (2018), Studying Gender in Medieval Europe: Historical Approaches (London, Palgrave Macmillan).

Smith, J. B. (ed.) (1972), Medieval Welsh Society: Selected Essays by T. Jones Pierce (Cardiff, University of Wales Press).

Smith, J. B. (1982-83), 'Dower in Thirteenth-century Wales: A Grant of the Commote of Anhuniog, 1277', Bulletin of the Board of Celtic Studies, 30: 348-55.

Smith, Ll. B. (2000), 'Towards a History of Women in Late Medieval Wales', in M. Roberts \& S. Clarke (eds) Women and Gender in Early Modern Wales (Cardiff, University of Wales Press), 14-49.

Stacey, R. C. (2000), 'King, Queen and Edling in the Laws of Court', in T. M. Charles-Edwards, M. E. Owen \& P. Russell (eds) The Welsh King and his Court (Cardiff, University of Wales Press), 29-62.

Stacey, R. C. (2002), 'Divorce, Medieval Welsh Style', Speculum, 77: 1107-27. https://doi.org/10.2307/3301214

Stacey, R. C. (2004), 'Learning to Plead in Medieval Welsh Law', Studia Celtica, 38: 107-23.

Stacey, R. C. (2018), Law and the Imagination in Medieval Wales (Philadelphia, PA, University of Pennsylvania Press). https://doi.org/10.9783/9780812295429

Stafford, P. \& Mulder-Bakker, A. (eds) (2002), Gendering the Middle Ages: A Gender and History Special Issue (Oxford, Blackwell).

Steger, M. B. (2008), The Rise of the Global Imaginary: Political Ideologies from the French Revolution to the Global War on Terror (Oxford and New York, Oxford University Press).

Stephen, B. (2018), 'That Trump Tank Meme on Cesar Sayoc's Van was Made as a Joke, Creator Says,' Verge, 26 October.https://www.theverge.com/2018/10/26/18029700/cesar-sayoc-democrat-bombstrump-tank-meme-joke [accessed 31 May 2019].

Stephenson, D. (1984), The Governance of Gwynedd (Cardiff, University of Wales Press).

Stephenson, D. (2000), 'The Laws of Court: Past Reality or Present Ideal?', in T. M. Charles-Edwards, M. E. Owen \& P. Russell (eds) The Welsh King and his Court (Cardiff, University of Wales Press), 400-14.

Stevens, M. (2010), Urban Assimilation in Post-Conquest Wales: Ethnicity, Gender and Economy in Ruthin, 1282-1348 (Cardiff, University of Wales Press).

Stone, R. (2012), Morality and Masculinity in the Carolingian Empire (Cambridge, Cambridge University Press). https://doi.org/10.1017/CBO9781139017473

Suppe, F. (1989), 'The Cultural Significance of Decapitation in High Medieval Wales and the Marches', Bulletin of the Board of Celtic Studies, 36: 147-60.

Swett, K. (1995), 'Widowhood, custom and property in early modern North Wales', Welsh History Review, 18: 189-227.

Taylor, C. (2003), Modern Social Imaginaries (Durham, NC, Duke University Press).

Taylor, C. (2004), 'On Social Imaginary', archive.org. https://web.archive.org/web/20041019043656/http://www.nyu.edu/classes/calhoun/Theory/Tayloron-si.htm [accessed 24 May 2019].

Teeman, T. (2016), 'The Not-so-hidden Meaning of Theresa May's Kitten Heels', The Daily Beast, 12 July. https://www.thedailybeast.com/the-not-so-hidden-meaning-of-theresa-mays-leopardprint-kitten-heels [accessed 31 May 2019].

Thorp, N. (2016), 'High-heels Campaigner: Why Theresa May Shouldn’t Wear Flat Shoes in the Name of Equality', The Telegraph, 15 September. https://www.telegraph.co.uk/women/politics/highheels-campaigner-why-theresa-may-shouldnt-wear-flat-shoes-i/ [accessed 31 May 2019].

Van Dijk, J. \& Nip, R. (eds) (2005), Saints, Scholars and Politicians: Gender as a Tool in Medieval Studies. Studies in Honour of Anneke Mulder-Bakker (Turnhout, Belgium, Brepols). https://doi.org/10.1484/M.MCS-EB.6.09070802050003050106050407 
Wade-Evans, A. W. (ed.) (1909), Welsh Medieval Law (Oxford, Clarendon Press; reprinted 1979, Aalen, Scientia).

Weikart K. \& Woodacre, E. (2016), 'Gender and Status in the Medieval World', Historical Reflections, 42(1): 1-7. https://doi.org/10.3167/hrrh.2016.420101

Wiliam, A. R. (ed.) (1960), Llyfr Iorwerth (Cardiff, University of Wales Press).

Wiliam, A. R. (ed.) (1988), Llyfr Cynghawsedd, Bulletin of the Board of Celtic Studies, 35: 73-85.

Wiliam, A. R. (ed.) (1990), Llyfr Cynog (Pamffledi Cyfraith Hywel; Aberystwyth, Centre for Advanced Welsh and Celtic Studies, University of Wales).

Williams, S. J. \& Powell, J. E. (eds) (1961), Cyfreithiau Hywel Dda yn ôl Llyfr Blegywryd (Cardiff, University of Wales Press).

Youngs, D. (2012), 'The Townswomen of Wales: Singlewomen, Work and Service, c. 1300-c. 1550', in H. Fulton (ed.), Urban Culture in Medieval Wales (Cardiff, University of Wales Press), 163-82.

To cite the article: Robin Chapman Stacey (2020), 'Gender and the social imaginary in medieval Welsh law', Journal of the British Academy, 8: 267-293.

DOI https://doi.org/10.5871/jba/008.267

Journal of the British Academy (ISSN 2052-7217) is published by

The British Academy, 10-11 Carlton House Terrace, London, SW1Y 5AH

www.thebritishacademy.ac.uk 
